\title{
SUNFLOWER CROP IN ARGENTINA TO DATE
}

\author{
Vasquez, A. ${ }^{*}$ and de Romano, A.
}

Nidera S.A. - C.C. 35 - CP 6013 Baigorrita, Buenos Aires, Argentina

Received: September 10, 2005 Accepted: March 25, 2006

\section{SUMMARY}

Inside a panorama of a spectacular grain production in the last 10 years in Argentina, sunflower crop participates with an annual production of more than $3,500,000 \mathrm{t}$.

During that period, many advances were made in the improvement of diseases resistance: Verticillium wilt, downy mildew and head rot. Also, oil yield per hectare continued to increase.

The new hybrids have new qualities, for example imidazolinones resistance, which allows farmers to keep yields, although the soils destined to sunflower are minor quality of those destined to corn and soybean.

\section{Key words: sunflower, grain production, sunflower diseases, hybrids}

\section{INTRODUCTION}

The agriculture in Argentina has attained a great increase of production during these last 10 years (Figure 1, source: SAGPyA and BCBA).

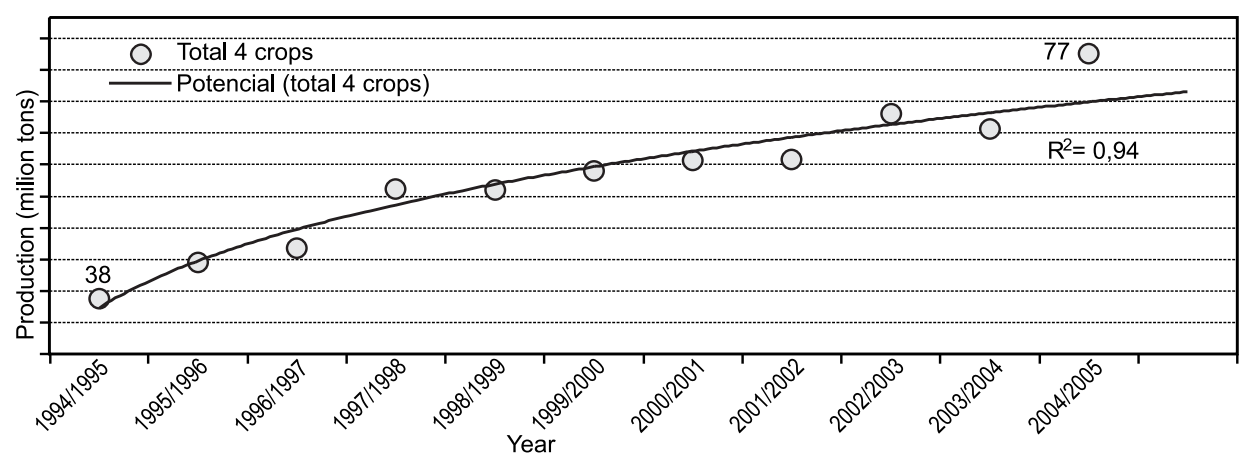

Figure 1: Total production of sunflower, soybean, wheat and corn in Argentina during the last 10 years

* Corresponding author, Phone/Fax: 542362 447036; 542362 446825,

e-mail: Nidera@redpower.com.ar 
In 1994/1995, the total production of sunflower, soybean, wheat and corn was 38 million tons; in the period 2004/2005, it was 77 million tons.

Soybean crop registered the largest increase; the increases in corn and wheat productions were less extensive (Figure 2, source: SAGPyA and BCBA).

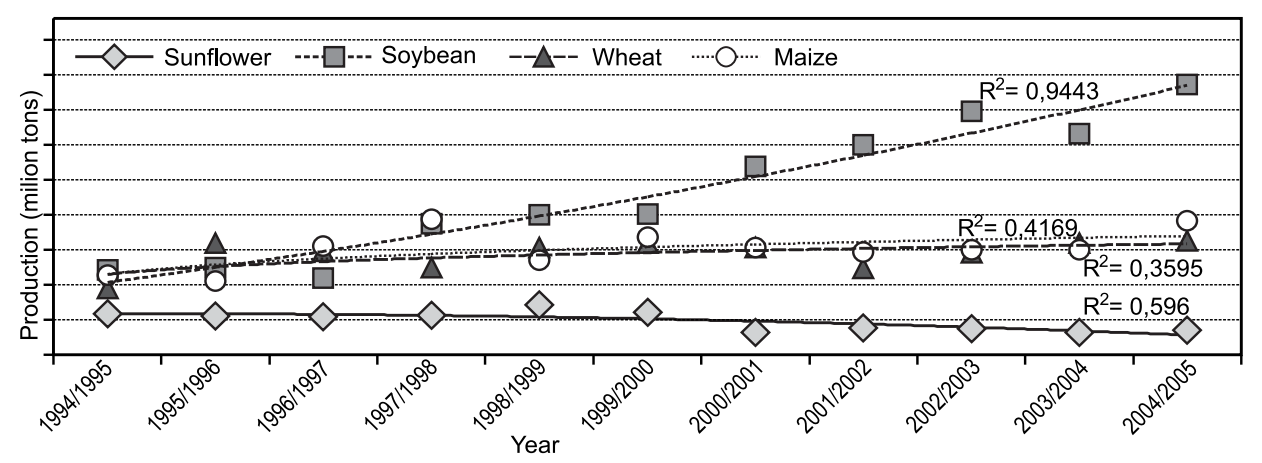

Figure 2: Crop production - evaluation of sunflower, soybean, wheat and corn in Argentina during the last 10 years

Lately, the sunflower area has decreased from more than 4,000,000 ha in 1998/ 99 to $1,873,000$ ha in 2005 . Consequently, the total sunflower production has registered a decrease (Figure 3, source: SAGPyA and BCBA).

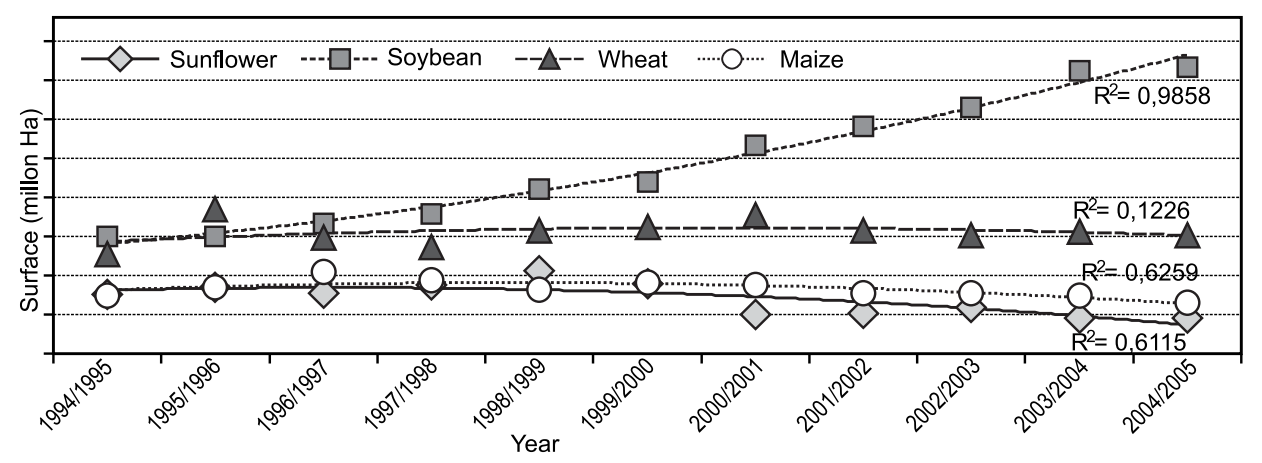

Figure 3: Crop acreage - evolution of the sunflower, soybean, wheat and corn in Argentina during the last 10 years

During this time, attention was paid to corn, soybean and wheat breeding and production technologies. Although new sunflower hybrids had high yield, they did not perform better than the above crops at farmer scale because they were grown on inferior soils.

\section{DISCUSSION}

In the period 2004/2005, sunflower was sown at $1,873,000$ ha rendering an average yield of $18.9 \mathrm{q} / \mathrm{ha}$. The total production volume was 3,525,000 $\mathrm{t}$ (Source: BCBA). 
Of the total acreage, about 50.000 ha were planted to confectionary sunflowers, nearly 100.000 ha to high oleic sunflowers and the rest was planted to conventional sunflowers.

Clearfield technology is being quickly used by Argentine farmers, and last year they have already sown 105,000 ha of Clearfield sunflower. This Clearfield acreage is expected to increase to 200.000 ha in $2005 / 2006$. This technology has been welcomed by those farmers that use the no tillering system. This no tillering system represents $37 \%$ of the sunflower sown surface during 2003/2004 season (Source: SAGPyA).

About fertilization, 53\% of the sunflower area has been fertilized with phosphorettes sources. This fertilization practice is applied at the sowing time. On the other hand, only $16 \%$ of the sunflower area has been fertilized with nitrogenous sources, which is applied in 4 to 6 pair leaves stage of the crop (Source: SAGPyA 2003/2004 season).

The breeding of sunflower has managed a great progress in the development of resistant hybrids to the main diseases; that is how about Verticilium dahliae Kleb, a disease present in $50 \%$ of the soil crop area (central and south region), the resistance has been introduced in the hybrids in such way up today $40 \%$ of the commercial hybrids are moderately resistant (Figure 4), although the no tillering system has the quality to reduce the damaged caused by Verticillium (Source: ASAGIR - INTA Balcarce and INTA Anguil - trials results 2004/2005).

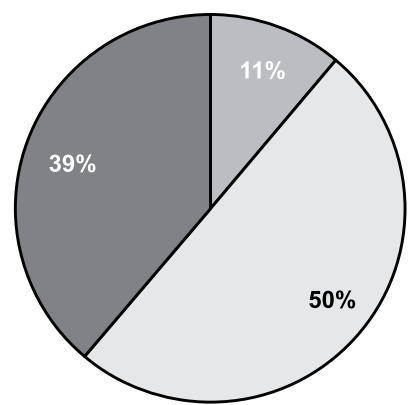

$1997 / 1998$

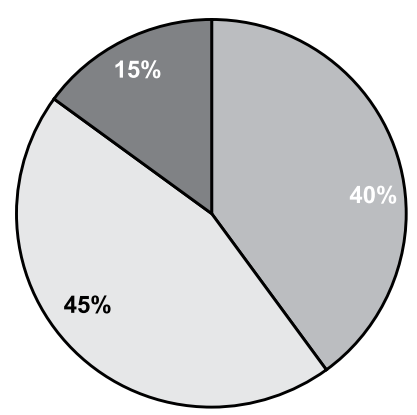

2004/2005

Figure 4: Sunflower crops behavior next to Verticillium wilt in Argentina from 1997/1998 to 2004/2005. Source: F. Quiroz, C. Troglia-ASAGIR-INTA Balcarce, 2004/2005.

About Plasmopara halstedii Berl - de Toni, it is a fungus present in all the crop area. At this moment, the main race is 770 . There are already 17 registered hybrids resistant to this race, and the rest of commercial hybrids are treated against this disease.

The head rot caused by Sclerotinia sclerotiorum Lib. de Bary is the most important way of this fungus, and it is present in central and south region. The assisted selection by ascosporic artificial inoculations has allowed developing hybrids with good behavior. Actually, according controls made by INTA Balcarce, 
$24 \%$ of the sown hybrids in Argentina have very good behavior to this disease (Figure 5).

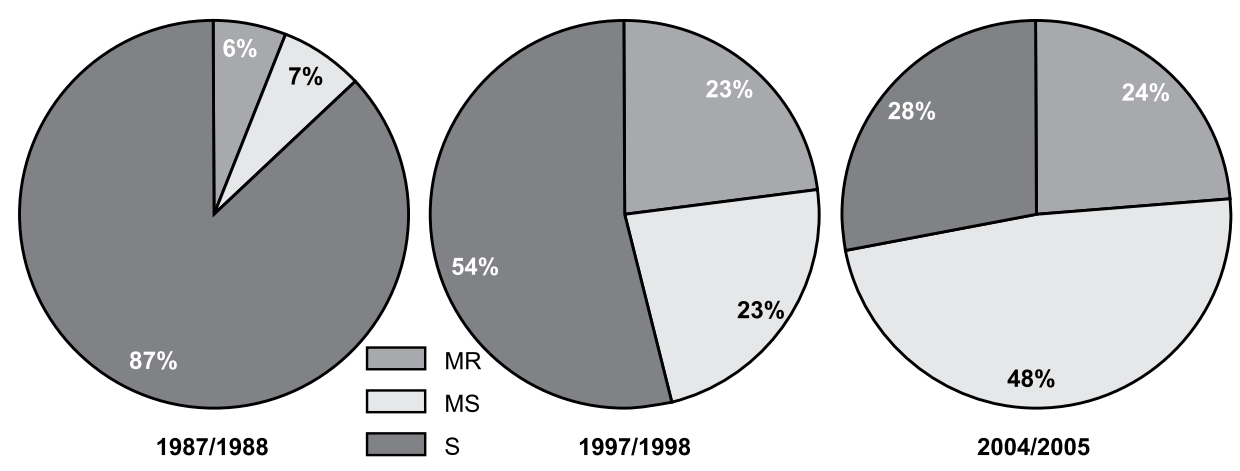

Figure 5: Evolution of sunflower commercial crops behavior next to head rot during last 17 years. Source: F. Quiroz, C. Troglia-ASAGIR-INTA Balcarce, 2004/2005.

About yield, the farmers have not obtained an average yield greater than $20 \mathrm{qq} /$ ha at country level during last years, although they have got very good yields in some regions at zone level, mainly during the last period 2004/2005. In the north region, the farmers average yield was $12 \mathrm{qq} / \mathrm{ha}$ due to the strong storms that happened before the harvest, which caused yield losses to the crops (Source: BCBA).

In the north of Santa Fe province, the average yield was $15 \mathrm{qq} / \mathrm{ha}$ on 100.000 sown ha. In Entre Rios province were sown 30.000 ha and the average yield was 20 $\mathrm{qq} / \mathrm{ha}$. In the central region of Santa Fe province, the average yield was $23 \mathrm{qq} / \mathrm{ha}$ on 17.000 ha (Source: BCBA).

The big region of south of Cordoba, north of La Pampa, northwest of Buenos Aires with 320.000 ha, has had very good yields of $24 \mathrm{qq} /$ ha on average, meanwhile the southeast of Buenos Aires with a big region of 700.000 ha has $19.6 \mathrm{qq} / \mathrm{ha}$ on average. On the other hand, the southeast of Buenos Aires and central of La Pompa with 470.000 ha had an average yield of $17 \mathrm{qq} /$ ha (Source: BCBA).

All these yields have been expressed in seed quintals per hectare without consider the oil percent reached in each region. It estimates that the average oil percent in the country is $48 \%$.

Actually, the Asociatión Argentina de Girasol (ASAGIR) has organized a big network of official trials. These trials have a conduction and design protocol for being easily interpreted by technicians and farmers in consultations.

The results are expressed in seed kg per ha, oil percent, oil kg per ha and bonified seed $\mathrm{kg}$ per hectare. This last values arises to consider the allowance that farmer gets for each point of oil percent that has the seed he sells, considering the base of $42 \%$.

Analysing the results of 8 trial locations conducted by ASAGIR - INTA in the southest of Buenos Aires, and considering the inscription date of each hybrid that 
participated in the trials, we could established that in last 10 years has been an advance in breeding of approximately $20 \mathrm{~kg}$ of bonified seed per year (Figure 6).

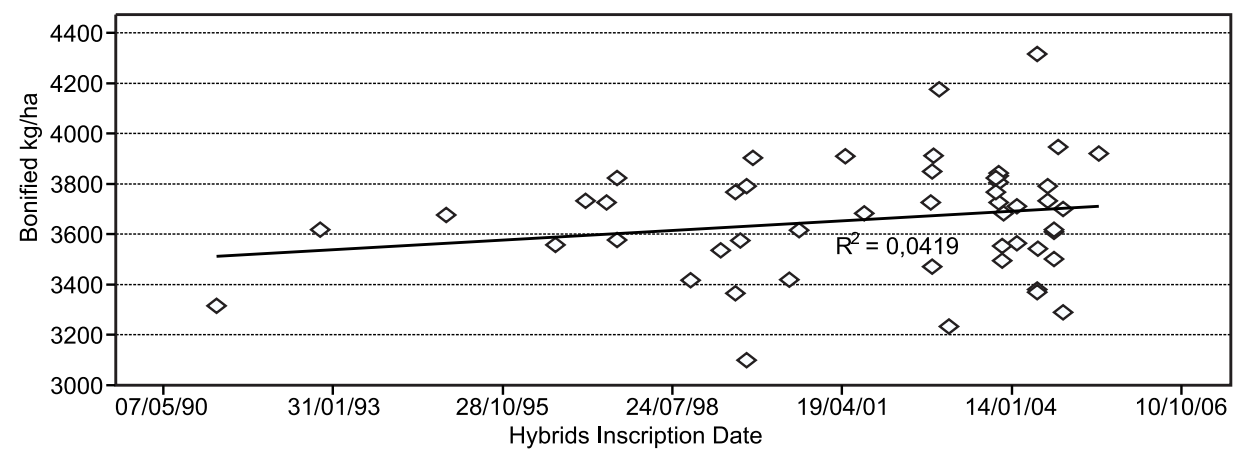

Figure 6: Increase of the bonified seeds $\mathrm{kg}$.

\section{CONCLUSION}

- The soybean crop replaced sunflower in the best crop areas.

- In spite of that, the average yield of sunflower seed per hectare did not fall down due to the achieved yield stability.

- The diseases resistance levels were increased in new hybrids.

- Clearfield technology was developed for improving weed control in sunflower without increase in phytotoxicity.

- The use of fertilizers keeps extending.

- More technical information can be obtained from the National Trials Network organized at 30 locations over last five years.

\section{REFERENCES}

SAGPyA: Secretarí de Agricultura, Ganadería, Pesca y Alimentacón (www. sagpya.gov.ar)

- Agricultura - Estimaciones agrícolas.

- Agricultura - Girasol - Siembra Direct Vs. Sidebar Convecional.

- Agricultura - Girasol - Fertilización.

BCBA: Bolsa de Cereales de Buenos Aires (www.bolsadecereales.com)

- Agriculture Panorama - Sowing- Harvest - Maps.

ASAGIR: Asociatión Argentina de Girasol (www.asagir.org.ar)

Evaluación de Cultivares Comerciales de Girasol en el Sur Bonaerense. Ensayos Campa a 2004/2005. Informe final de rendimiento, aceite, sanidad, fenología y altura.

Victoria Quillehauquy - Carolina Troglia - Facundo Quiroz (INTA Balcarce).

\section{ACKNOWLEDGEMENTS}

We thank Sandra Piriz from Nidera S.A. for translating the manuscript and making the drawings. 


\title{
EL CULTIVO DE GIRASOL EN ARGENTINA AL DÍA DE HOV
}

\author{
RESUMEN
}

En un panorama de incrementos de producción de granos espectacular en los últimos 10 años en Argentina, el cultivo de girasol participa con una producción anual de más de 3.500.000 toneladas.

Durante ese lapso se han logrado avances en el mejoramiento de la resistencia a Verticilium, downy mildew y Sclerotinia, además de incrementos continuos en los rindes de aceite por hectárea.

Los nuevos híbridos tienen nuevas cualidades, por ejemplo la resistencia a imidazolinonas, que permiten al agricultor sostener los rendimientos a pesar de destinar a este cultivo suelos de menor jerarquía que utilizados para maíz y soja.

\section{LA CULTURE DU TOURNESOL EN ARGENTINE JUSQU'À MAINTENANT}

\section{RÉSUMÉ}

Dans le panorama des succès spectaculaires atteints dans la culture des grains en Argentine au cours des dix dernières années, la part du tournesol est de plus de 3,500,000 t. par année.

$\mathrm{Au}$ cours de cette période de nombreux progrès ont été faits dans l'amélioration de la résistance aux maladies : la flétrissure par le Verticillium, le mildiou et la pourriture de la tête. On a aussi noté du progrès dans la production d'huile par hectare.

Les nouveaux hybrides ont de nouvelles qualités, par exemple la résistance aux imidazolinones qui permet aux fermiers de maintenir un haut niveau de production malgré le fait que les sols utilisés pour la production du tournesol soit de qualité inférieure à celle des sols utilisés pour la culture du maïs et du soja. 